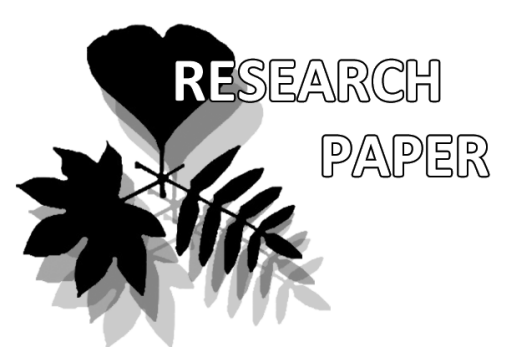

\title{
Plant regeneration from cotyledon and leaf explants of Ceropegia bulbosa Roxb. an endangered medicinal plant
}

\author{
Balakrishnan Subbaiyan * \& Vellaichamy Thangapandian
}

Balakrishnan Subbaiyan* e-mail: bsubbaiyan@gmail.com

Vellaichamy Thangapandian

e-mail: drvthangapandian@gmail.com

PG and Research Department of Botany, Kongunadu Arts and Science College [Autonomous], Coimbatore, Tamil Nadu, India

\section{* corresponding author}

Manuscript received: 22.08.2017 Review completed: 14.11.2017 Accepted for publication: 21.11.2017 Published online: 26.11.2017

\begin{abstract}
A B S T R A C T
An efficient protocol of callus induction, shoot multiplication and plant regeneration from cotyledon and leaf explants of Ceropegia bulbosa has been elaborated. The highest percentage (90.66) of callus induction was observed when cotyledonary explants cultured on MS medium having $0.5 \mathrm{mg} / \mathrm{L} \mathrm{2,4-D}$ in combination with $0.05 \mathrm{mg} / \mathrm{L} \mathrm{Kn}$ followed by $86.25 \%$ callus induction from leaf explant at $0.5 \mathrm{mg} / 1 \mathrm{BAP}$ in combination with $0.05 \mathrm{mg} / 1 \mathrm{Kn}$. Shoot multiplication was observed, cotyledon derived callus cultured on $1.0 \mathrm{mg} / \mathrm{L}$ BAP in combination with $0.10 \mathrm{mg} / \mathrm{L}$ NAA could induce number of shoots (4.71) and their lengths $(6.13$ $\mathrm{cm})$. Cotyledonary callus derived microshoots gave the highest rooting percentage $(92.26 \%)$ root numbers $(13.14)$ and their lengths $(8.87 \mathrm{~cm})$ were observed on half-strength MS medium fortified with $0.4 \mathrm{mg} / \mathrm{L}$ IBA. In vitro derived plantlets were hardened in the greenhouse and successfully established into the soil.

K e y w o r d s : Ceropegia, cotyledon, 2, 4-D, plant regeneration, microshoots
\end{abstract}

\section{P E 3 Ю M E}

Суббайан Б., Тангапандян В. Регенерация растений их семядолей и мистьев Ceropegia bulbosa Roxb., редкого мекарственного растения. Разработан эффективный метод индукции калцюса, размножения побегов и регенерации растений из семядолей и эксплантатов Аистьев Ceropegia bulbosa. Наибольший процент $(90,66)$ индукции калАюса наблюАался, когАа семядольные эксплантаты культивировали на MS-среде, имеющей 0,5 мг/ 2,4-D, в комбинации с 0,05 мг / $\Lambda$ Kn. 86,25 \% индукции камлюса из эксплан-

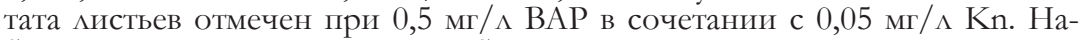
блюдалось увеличение числа побегов: калАюс, полученный из семядолей, культивируемый на 1,0 мг/ ВАР в сочетании с 0,10 мг / $\mathrm{NAA}$, мог индуцировать в среднем 4,71 побегов Алиной 6,13 см. Побеги, полученные из калАюса семядоли на среде MS, обогащенной 0,4 мг/ IBA, Аали наивысший процент корней $(92,26 \%$ ) (общее число - 13,14) Алиной в среднем 8,87 см. Полученные in vitro проростки прошли аАаптацию в теплице и успешно внедрены в почву.

Переведено редакиией.

КАючевые слова: Ceropegia, семядоля, 2, 4-D, регенерация растений, микропобеги
Ceropegia bulbosa Roxb. is an important medicinal plant that has tuber, which is traditionally used for urinary disorders and its decoction is also considered to be a digestive and healthy tonic (Swarnkar \& Katewa 2008, Phulwaria et al. 2013). The plant is often harvested from the wild for its edible leaves and tubers, which are used locally as vegetable and food. It is growing in natural habitats with limited number of tubers that survive and being dormant in soil and produce the new plant in the next season. At the same time population of this species gets reduced due to continuous consumption of tubers by animals and drying or deterioration of tubers in drought and water logging conditions respectively. Continuous collection or over exploitation of C. bulbosa is must both for food and pharmaceuticals sources. It is under threat due to destructive collection of leaves and tubers or habitat degradation by grazing, scarcity of pollinators and poor seed setting quality, low viability and low germination capability (Goyal \& Bhadauria 2006, Yadav \& Kamble 2008). As these are the continuous problems in India, C. bulbosa classified under the RET category (BSI 2002, Goyal \& Bhadauria 2006).
It is possible to conserve this species from drastic exploitation by applying effective propagation methods so as to remove from the RET list. Though C. bulbosa can be propagated through the seeds and tubers, it is not enough to establish its population in its own habitats as we expect. Early research reports proved that taxonomicaly close species C. intermedia (Karuppusamy et al. 2007), C. odorata (Srinivasarao et al. 2010) have poor seed germination capacity. Therefore, it is an urgent need for the establishment of an efficient in vitro regeneration method for their conservation. Plant tissue culture techniques are an alternate tool for the conservation of medicinal and RET listed plants (Thiyagarajan \& Venkatachalam 2012).

Reinforcement of wild plant population using individuals raised ex situ is considered a wailed means of reducing the risk of threatened species (Bowes 1999). Many plant species respond well to in vitro conditions, including rich medium and also plant growth hormones (Cerabolini et al. 2004). Micropropagation of C. juncea (Krishnareddy et al. 2011) and C. mahabalei (Upadhye et al. 2014) were reported earlier. 
As Ceropegia bulbosa is highly deserved for the modern drug development process and is permanently demanded as a stable food by many tribal's peoples, the status of the plant is continuously being either under a poorly available or non-available category. Consequently it is facing threats. Further, this condition develops pressure in commercial demand. Therefore, the steps taken to increase its population will ensure the availability of the greater biomass, which is more essential to meet the demand thereby it bestows the conservation of this species as well. Hence, the present investigation was taken as a challenge to have a mass propagation using the cotyledon and leaf explants excised from the seedlings emerged after seed treatments by breaking the seed dormancy for in vitro culture.

\section{MATERIAL AND METHODS}

\section{Explant sterilization}

Explants were excised from the healthy seedlings and these explants were transferred to $250 \mathrm{ml}$ sterile conical flask. They were washed first under running tap water for 3-5 minutes and treated with $0.1 \%(\mathrm{v} / \mathrm{v})$ Tween-20 for 5 minutes followed by $0.5 \%$ of Bavistin for 1 minute to remove the unwanted microorganisms adhered on them. Then they were repeatedly rinsed in distilled water. Further sterilization was done under aseptic environment in a laminar air-flow hood. Here the explants were surface sterilized with $20 \%(\mathrm{v} / \mathrm{v})$ ethanol for a minute and then by $0.1 \%(\mathrm{v} / \mathrm{v})$ $\mathrm{HgCl}_{2}$ for $2-3$ minutes. Finally, the explants were thoroughly washed (up to 6-8 times) with sterilized double distilled water. Thus pathogen free and healthy sterilized explants were inoculated for in vitro culture on the MS medium.

\section{Culture media and conditions}

MS basal medium containing different concentrations of plant growth regulators, auxins and cytokinins, were used either individually or in combination. After the media adjusted to optimum $\mathrm{pH}$ values range from 5.6 to 5.8 about $8 \mathrm{~g} / \mathrm{l}$ agar was added. Finally MS medium, with necessary composition or in combination, was autoclaved at $121^{\circ} \mathrm{C}$ under $103 \mathrm{kPa}$ for 30 minutes. This sterilized media was then transferred to an aseptic environmental condition provided at the working place of the laboratory. Cultures were incubated at $25 \pm 1^{\circ} \mathrm{C}$ with $16 \mathrm{hrs}$ photoperiod under cool white fluorescent tubes (Philips L $58 \mathrm{~W} / 640,30 \mu \mathrm{mol} \mathrm{m} \mathrm{m}^{-2} \mathrm{~S}-1$ $\mathrm{PPF}$ ) and maintained between $75-80 \%$ relative humidity.

\section{Callogenesis (indirect organogenesis)}

Aseptically excised cotyledon and leaf explants, from the seedlings emerged from the treated seeds, were cultured on MS basal medium supplemented with five different concentrations of $(0.5,1.0,2.0,3.0,4.0 \mathrm{mg} / \mathrm{l}) 2,4 \mathrm{D}, \mathrm{BAP}$, and TDZ alone or in combination with five different concentrations of $\mathrm{Kn}(0.05,0.10,0.20,0.30$ and $0.40 \mathrm{mg} / \mathrm{l})$ for callus induction. Every 4th week the mature callus was subcultured on the same combination of fresh medium. At the end of the first 4th week culture, the efficiency of PGRs on callus induction was recorded by estimating the percentage of explants survival and days required for callus induction.

\section{Effects of BAP, NAA and IBA on shoot regeneration}

Mature callus emerged from the cotyledon and leaf explants were transferred into MS medium fortified with three different concentrations of $(0.5,1.0$ and $2.0 \mathrm{mg} / \mathrm{l}) \mathrm{BAP}$ and NAA alone or in combination of BAP or TDZ with three different concentrations of NAA $(0.05,0.10$ and $0.20 \mathrm{mg} / \mathrm{l})$ for evaluation of shoot regeneration. At the end of the 4th week, number of shoots generated by per explant and their lengths were calculated and recorded.

\section{Effects of temperature and photoperiod on shoot multiplication}

All the cultures were maintained at the culture room under $25 \pm 1^{\circ} \mathrm{C}$ temperature and $65-70 \%$ relative humanity. The cultures were kept under white light at the intensity of 3000 lux provided from white fluorescence lambs (Philips, India) with $16 \mathrm{hrs}$ photoperiod duration.

\section{Root organogenesis}

2 to $5 \mathrm{~cm}$ long in vitro regenerated shoots were cultured on half strength MS medium fortified individually with the similar concentrations $(0.2,0.4,0.6,0.8$ and $1.0 \mathrm{mg} / \mathrm{l})$ of IBA, IAA and NAA to check their root induction abilities. Percentage of root induction, number of roots regenerated per shoot explant and their lengths were recorded from the 4 weeks old culture.

\section{Hardening for acclimatization}

In vitro regenerated plantlets were individually potted and maintained at $90 \%$ relative humidity in a mist chamber for three weeks. The acclimatized plantlets were subsequently transferred to individual pot that contained a mixture of same quantity of three different composition media, which were, Sand: Soil: Vermiculite $(1: 1: 1, v / v)$, Forest soil: Soil: Vermiculite (1:1:1, v/v) and Garden soil: Soil: Vermiculite $(1: 1: 1, \mathrm{v} / \mathrm{v})$. All the pots were shifted to greenhouse and regularly watered. The survival percentage of the acclimatized plantlets was calculated and recorded from all the three treatments after two weeks of incubation period.

\section{Statistical analysis}

The cultures were periodically observed and morphological changes were recorded at regular intervals. Each experiment was repeated with 20 replicates. Callus induction, shoot and root regeneration and the number of shoots and roots emerged per explant and their lengths were recorded 4 weeks after the culture. Analysis of variance (ANOVA) was performed on all data to compare concentration and combination effects of the growth regulators. Means were segregated using Duncan's Multiple Range Test (DMRT).

\section{RES U LTS}

\section{Callus organogenesis}

Application of different concentrations of plant growth regulators is essential to understand the optimum requirement for the callus induction in C. bulbosa. None of the callusing response was noted on the basal medium. BAP, 2,4$\mathrm{D}$, TDZ in combination with $\mathrm{Kn}$ were used in the medium to check their influence on callus induction ability of coty- 
ledon and leaf explants of C. bulbosa two weeks after inoculation and these details are presented in Table 1. First callus induction was observed on 11 days after inoculation from the cotyledonary explants of C. bulbosa on the medium containing $0.5 \mathrm{mg} / 1 \mathrm{BAP}$ in combination with $0.05 \mathrm{mg} / 1 \mathrm{Kn}$, followed by the same concentrations 2,4-D in combination with $\mathrm{Kn}$, where the callus induction was noted 12 days after inoculation (Fig. 1).

The leaf explants required 14 to 17 days after culture to induce callus formation. $74.19 \%$ callus formation was observed from cotyledon explants were cultured on MS medium fortified with $0.5 \mathrm{mg} / 12$,4-D alone. The high percentage $(90.66 \%)$ of callus induction was observed, when cotyledonary explants were cultured on MS medium having $0.5 \mathrm{mg} / 1$ 2,4-D in combination with $0.05 \mathrm{mg} / 1 \mathrm{Kn}$ and followed by $86.25 \%$ callus induction was observed from the same explants cultured on MS medium supplemented with $0.5 \mathrm{mg} / \mathrm{L}$ BAP in combination with $0.05 \mathrm{mg} / 1 \mathrm{Kn}$. However, the leaf explants induced $76.23 \%$ callus formation on MS medium fortified with $0.5 \mathrm{mg} / 1 \mathrm{BAP}$ in combination with $0.05 \mathrm{mg} / 1 \mathrm{Kn}$ and $69.22 \%$ callus formation was observed on MS medium fortified with $0.5 \mathrm{mg} / 12,4-\mathrm{D}$ in combination with $0.05 \mathrm{mg} / 1 \mathrm{Kn}$. This investigation suggests that the 2,4-D, BAP in combination with $\mathrm{Kn}$ could exhibit the effective for callus formation from the cotyledonary explants of C. bulbosa.

\section{Shoot regeneration}

The matured callus was subcultured on the MS Medium contained different concentrations and combinations of
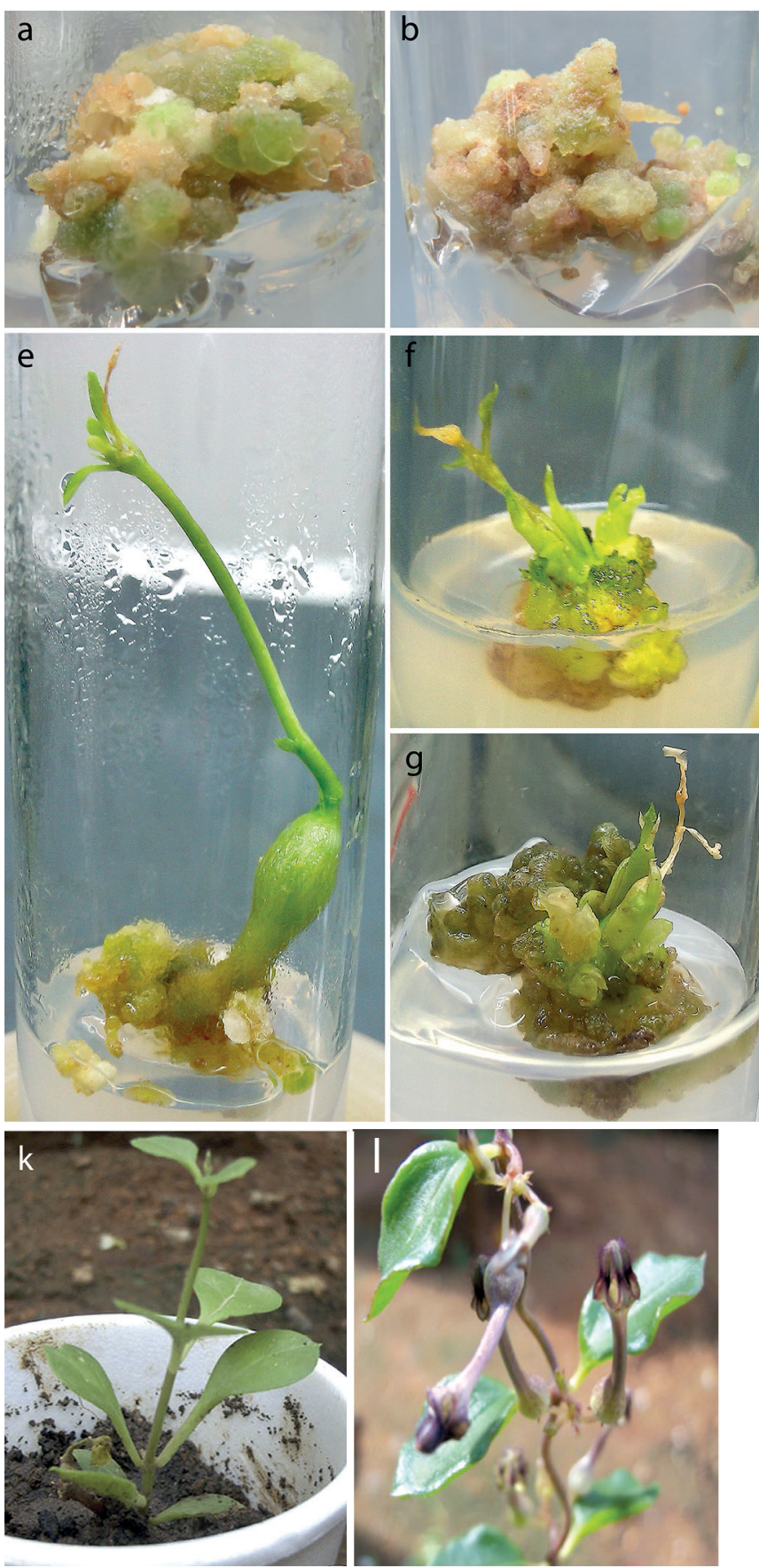
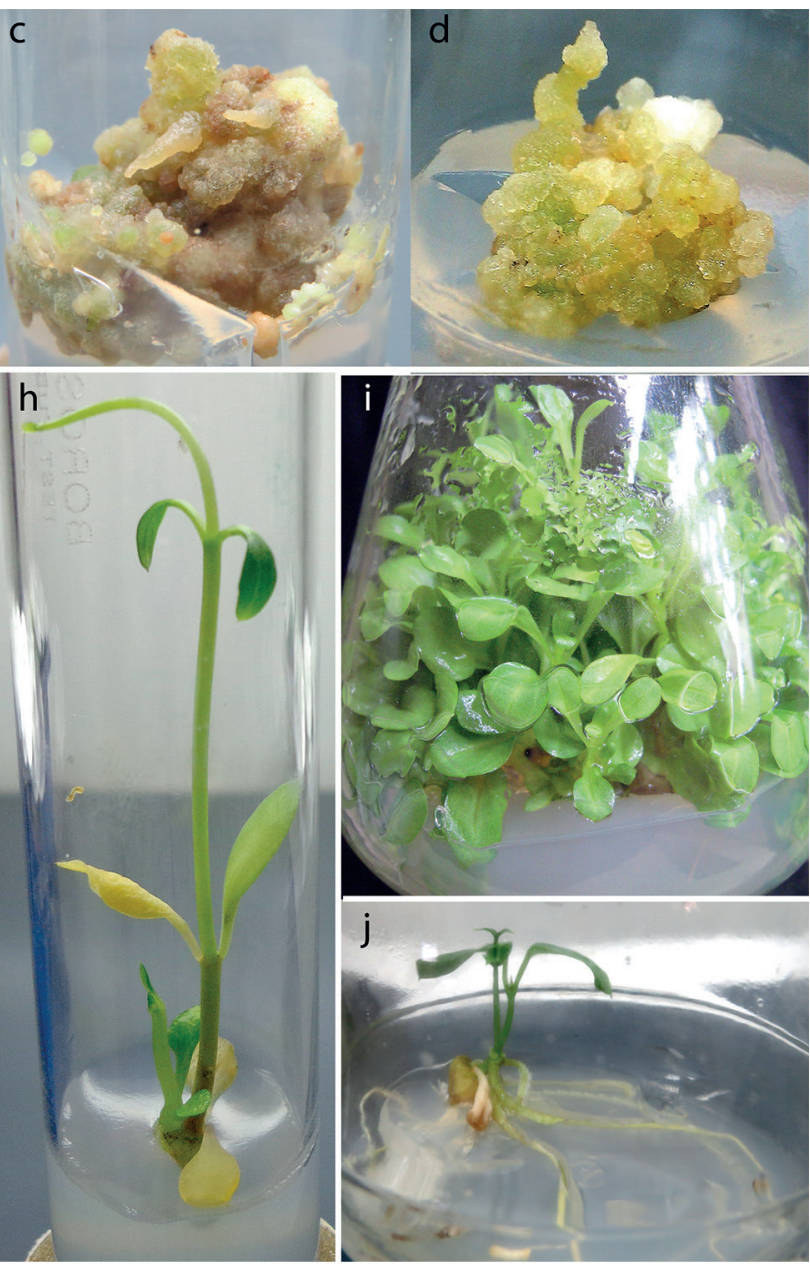

Figure 1 Callus induction and plant regeneration from cotyledon, leaf explants of Ceropegia bulbosa. a-b: $0.5 \mathrm{mg} / \mathrm{L} 2,4 \mathrm{D}$ with combination of $0.05 \mathrm{mg} / \mathrm{L} \mathrm{Kn}$ induced callus formation; c-d: callus formation by TDZ and combination with Kn; e: tuber formation; f-g: shoot initiation from callus culture on $1.0 \mathrm{mg} / \mathrm{L}$ BAP with 0.10 mg/L NAA; h-i: multishoots formation; j: rooting; k: hardening; 1: habit with flowers 
Table 1. Callus induction efficiency of cotyledon, leaf segments excised from the seedlings emerged from the treated seeds on MS medium supplemented with different concentrations of BAP, 2,4-D and TDZ in combination with Kn. Each value represents the Mean $\pm S D, n=20$. Mean followed by the same letters in each column are not significantly different at $\mathrm{P}<0.05$ according to Duncan's multiple range test

\begin{tabular}{|c|c|c|c|c|c|c|c|c|}
\hline \multirow{2}{*}{ S. No. } & \multicolumn{4}{|c|}{ Plant growth regulators $(\mathrm{mg} / \mathrm{L})$} & \multicolumn{2}{|c|}{ Days required for callus induction } & \multicolumn{2}{|c|}{ Percentage of callus induction } \\
\hline & BAP & $2,4-\mathrm{D}$ & TDZ & $\mathrm{Kn}$ & Cotyledon & Leaf & Cotyledon & Leaf \\
\hline 1 & 0.5 & 0.0 & 0.0 & 0.0 & 12 & 13 & $73.44 \pm 0.62^{\mathrm{ef}}$ & $68.40 \pm 0.64^{c}$ \\
\hline 2 & 1.0 & 0.0 & 0.0 & 0.0 & 13 & 15 & $71.07 \pm 1.0^{g}$ & $63.96 \pm 0.81^{\mathrm{f}}$ \\
\hline 3 & 2.0 & 0.0 & 0.0 & 0.0 & 24 & 23 & $66.20 \pm 0.87^{\mathrm{h}}$ & $65.29 \pm 0.64^{\mathrm{e}}$ \\
\hline 4 & 0.0 & 0.5 & 0.0 & 0.0 & 11 & 14 & $74.19 \pm 0.89^{\mathrm{e}}$ & $71.15 \pm 0.81^{\mathrm{b}}$ \\
\hline 5 & 0.0 & 1.0 & 0.0 & 0.0 & 16 & 17 & $64.34 \pm 1.12^{\mathrm{i}}$ & $67.26 \pm 0.56^{\mathrm{d}}$ \\
\hline 6 & 0.0 & 2.0 & 0.0 & 0.0 & 19 & 22 & $63.34 \pm 1.40^{\mathrm{k}}$ & $57.16 \pm 1.10^{\mathrm{hi}}$ \\
\hline 7 & 0.0 & 0.0 & 0.5 & 0.0 & 12 & 15 & $64.44 \pm 0.48^{i}$ & $64.98 \pm 0.57^{\mathrm{ef}}$ \\
\hline 8 & 0.0 & 0.0 & 1.0 & 0.0 & 17 & 18 & $62.54 \pm 0.76^{\mathrm{lm}}$ & $57.86 \pm 0.96^{\mathrm{hi}}$ \\
\hline 9 & 0.0 & 0.0 & 2.0 & 0.0 & 19 & 23 & $60.30 \pm 0.62^{\mathrm{m}}$ & $60.33 \pm 0.83^{g}$ \\
\hline 10 & 0.5 & 0.0 & 0.0 & 0.05 & 11 & 15 & $86.25 \pm 0.36^{\mathrm{b}}$ & $76.23 \pm 0.87^{\mathrm{a}}$ \\
\hline 11 & 1.0 & 0.0 & 0.0 & 0.10 & 13 & 17 & $77.57 \pm 0.84^{\mathrm{d}}$ & $61.54 \pm 0.97^{\mathrm{fg}}$ \\
\hline 12 & 2.0 & 0.0 & 0.0 & 0.20 & 15 & 19 & $72.20 \pm 1.27^{\mathrm{fg}}$ & $56.24 \pm 0.97^{\mathrm{ij}}$ \\
\hline 13 & 3.0 & 0.0 & 0.0 & 0.30 & 19 & 26 & $66.96 \pm 1.21^{\mathrm{h}}$ & $57.18 \pm 0.72^{\mathrm{i}}$ \\
\hline 14 & 4.0 & 0.0 & 0.0 & 0.40 & 23 & 27 & $62.18 \pm 0.62^{\mathrm{lm}}$ & $46.74 \pm 0.84^{\mathrm{m}}$ \\
\hline 15 & 0.0 & 0.5 & 0.0 & 0.05 & 13 & 15 & $90.66 \pm 0.04^{\mathrm{a}}$ & $69.22 \pm 0.59^{\mathrm{bc}}$ \\
\hline 16 & 0.0 & 1.0 & 0.0 & 0.10 & 15 & 18 & $80.47 \pm 0.55^{c}$ & $56.42 \pm 1.08^{i j}$ \\
\hline 17 & 0.0 & 2.0 & 0.0 & 0.20 & 17 & 21 & $74.29 \pm 0.86^{\mathrm{e}}$ & $59.23 \pm 0.87^{g}$ \\
\hline 18 & 0.0 & 3.0 & 0.0 & 0.30 & 22 & 26 & $62.18 \pm 0.71^{1 \mathrm{~m}}$ & $55.49 \pm 0.26$ \\
\hline 19 & 0.0 & 4.0 & 0.0 & 0.40 & 26 & 29 & $56.99 \pm 0.93^{\mathrm{n}}$ & $51.25 \pm 0.87^{\mathrm{k}}$ \\
\hline 20 & 0.0 & 0.0 & 0.5 & 0.05 & 14 & 16 & $76.91 \pm 0.22^{\mathrm{de}}$ & $62.21 \pm 0.96^{\mathrm{f}}$ \\
\hline 21 & 0.0 & 0.0 & 1.0 & 0.10 & 16 & 19 & $72.18 \pm 0.62^{\mathrm{fg}}$ & $57.08 \pm 0.21^{\mathrm{gh}}$ \\
\hline 22 & 0.0 & 0.0 & 2.0 & 0.20 & 18 & 21 & $65.40 \pm 0.59^{\mathrm{hi}}$ & $62.93 \pm 1.00^{\mathrm{f}}$ \\
\hline 23 & 0.0 & 0.0 & 3.0 & 0.30 & 23 & 26 & $63.81 \pm 0.42^{\mathrm{k}}$ & $52.54 \pm 1.09^{\mathrm{k}}$ \\
\hline 24 & 0.0 & 0.0 & 4.0 & 0.40 & 27 & 29 & $56.29 \pm 1.46^{\mathrm{n}}$ & $48.58 \pm 0.91^{1}$ \\
\hline
\end{tabular}

Table 2. Shoot induction efficiency of cotyledon and leaf derived callus of C. bulbosa seedlings emerged from the treated seeds on MS medium containing different concentrations and combinations of auxins and cytokinins. Each value represents the Mean $\pm \mathrm{SD}, \mathrm{n}=20$. Mean followed by the same letters in each column are not significantly different at $\mathrm{P}<0.05$ according to Duncan's multiple range test

\begin{tabular}{|c|c|c|c|c|c|c|c|c|c|}
\hline \multirow{2}{*}{ S. No. } & \multicolumn{3}{|c|}{$\begin{array}{c}\text { Plant growth } \\
\text { regulators }(\mathrm{mg} / \mathrm{L})\end{array}$} & \multicolumn{3}{|c|}{ Cotyledon derived callus } & \multicolumn{3}{|c|}{ Leaf derived callus } \\
\hline & BA & NAA & IBA & $\begin{array}{l}\% \text { of culture } \\
\text { response }\end{array}$ & $\begin{array}{l}\text { No. of shoots/ } \\
\text { callus }\end{array}$ & $\begin{array}{l}\text { Average shoot } \\
\text { length }(\mathrm{cm})\end{array}$ & $\begin{array}{l}\% \text { of culture } \\
\text { response }\end{array}$ & $\begin{array}{l}\text { No. of shoots / } \\
\text { callus }\end{array}$ & $\begin{array}{l}\text { Average shoot } \\
\text { length }(\mathrm{cm})\end{array}$ \\
\hline 1 & 0.0 & 0.0 & 0.0 & 0.0 & 0.0 & 0.0 & 0.0 & 0.0 & 0.0 \\
\hline 2 & 0.5 & 0.0 & 0.0 & $64.41 \pm 1.31^{\mathrm{h}}$ & $3.11 \pm 0.04^{\mathrm{lj}}$ & $4.25 \pm 0.54^{\mathrm{e}}$ & $63.36 \pm 1.13^{\mathrm{i}}$ & $2.51 \pm 0.50^{\mathrm{g}}$ & $3.15 \pm 0.13^{\mathrm{i}}$ \\
\hline 3 & 1.0 & 0.0 & 0.0 & $68.06 \pm 0.24^{\mathrm{f}}$ & $3.29 \pm 0.08^{i j}$ & $5.04 \pm 0.18^{\mathrm{cd}}$ & $65.02 \pm 1.0^{\mathrm{fg}}$ & $2.59 \pm 0.30^{\mathrm{g}}$ & $4.70 \pm 0.52^{\mathrm{e}}$ \\
\hline 4 & 2.0 & 0.0 & 0.0 & $65.89 \pm 0.82^{g}$ & $2.91 \pm 0.09^{\mathrm{k}}$ & $3.96 \pm 0.06^{\mathrm{f}}$ & $60.47 \pm 1.07^{\mathrm{jk}}$ & $2.91 \pm 0.09^{\mathrm{f}}$ & $4.02 \pm 0.21^{\mathrm{ef}}$ \\
\hline 5 & 0.0 & 0.5 & 0.0 & $58.0 \pm 0.07^{1}$ & $3.06 \pm 0.05^{\mathrm{ij}}$ & $5.56 \pm 0.45^{b c}$ & $61.88 \pm 1.14^{i}$ & $3.01 \pm 0.23^{\mathrm{de}}$ & $3.50 \pm 0.50^{\mathrm{gh}}$ \\
\hline 6 & 0.0 & 1.0 & 0.0 & $63.51 \pm 0.54^{\mathrm{hi}}$ & $3.85 \pm 0.26^{\mathrm{ef}}$ & $5.25 \pm 0.54^{\mathrm{bc}}$ & $65.66 \pm 0.73^{\mathrm{fg}}$ & $3.16 \pm 0.27^{\mathrm{d}}$ & $3.98 \pm 0.12^{\mathrm{g}}$ \\
\hline 7 & 0.0 & 2.0 & 0.0 & $61.59 \pm 0.56^{\mathrm{k}}$ & $3.54 \pm 0.46^{\mathrm{gh}}$ & $3.66 \pm 0.76^{\mathrm{g}}$ & $60.29 \pm 0.63^{\mathrm{k}}$ & $2.98 \pm 0.10^{\mathrm{e}}$ & $4.0 \pm 0.12^{\mathrm{ef}}$ \\
\hline 8 & 0.5 & 0.05 & 0.0 & $75.58 \pm 0.54^{c}$ & $4.67 \pm 0.18^{b}$ & $5.81 \pm 0.49^{\mathrm{ab}}$ & $70.67 \pm 0.58^{\mathrm{cd}}$ & $4.26 \pm 0.69^{\mathrm{ab}}$ & $5.14 \pm 0.07^{\mathrm{b}}$ \\
\hline 9 & 1.0 & 0.10 & 0.0 & $90.91 \pm 0.72^{\mathrm{a}}$ & $4.71 \pm 0.26^{\mathrm{a}}$ & $6.13 \pm 0.10^{\mathrm{a}}$ & $82.44 \pm 0.76^{\mathrm{a}}$ & $4.37 \pm 0.30^{\mathrm{a}}$ & $5.78 \pm 0.30^{\mathrm{a}}$ \\
\hline 10 & 2.0 & 0.20 & 0.0 & $71.89 \pm 0.82^{\mathrm{d}}$ & $4.36 \pm 0.45^{\mathrm{cd}}$ & $5.41 \pm 0.44^{\mathrm{bc}}$ & $58.54 \pm 0.46^{1}$ & $3.81 \pm 0.24^{\mathrm{c}}$ & $5.07 \pm 0.49^{\mathrm{bc}}$ \\
\hline 11 & 0.0 & 0.5 & 0.05 & $72.7 \pm 0.67^{\mathrm{d}}$ & $3.80 \pm 0.17^{\mathrm{fg}}$ & $5.0 \pm 0.11^{\mathrm{cd}}$ & $64.55 \pm 0.78^{\mathrm{hi}}$ & $4.18 \pm 0.63^{b}$ & $4.84 \pm 0.18^{\mathrm{d}}$ \\
\hline 12 & 0.0 & 1.0 & 0.10 & $76.57 \pm 0.01^{c}$ & $4.03 \pm 0.17^{\text {def }}$ & $5.32 \pm 0.23^{b c}$ & $72.30 \pm 0.81^{b}$ & $4.15 \pm 0.11^{\mathrm{bc}}$ & $5.05 \pm 0.37^{\mathrm{bc}}$ \\
\hline 13 & 0.0 & 2.0 & 0.20 & $62.73 \pm 0.67^{i}$ & $3.95 \pm 0.37^{\mathrm{cd}}$ & $5.08 \pm 0.20^{\mathrm{e}}$ & $66.59 \pm 0.56 \mathrm{e}^{\mathrm{f}}$ & $3.30 \pm 0.27^{\mathrm{cd}}$ & $4.22 \pm 0.23^{\mathrm{e}}$ \\
\hline 14 & 0.5 & 0.0 & 0.05 & $71.56 \pm 0.49^{\mathrm{de}}$ & $4.18 \pm 0.31^{\mathrm{cde}}$ & $5.14 \pm 0.07^{\mathrm{de}}$ & $68.23 \pm 1.00^{\mathrm{d}}$ & $2.91 \pm 0.07^{\mathrm{f}}$ & $3.76 \pm 0.50^{\mathrm{h}}$ \\
\hline 15 & 1.0 & 0.0 & 0.10 & $81.56 \pm 0.50^{\mathrm{b}}$ & $4.32 \pm 0.46^{b}$ & $5.17 \pm 0.09^{\mathrm{de}}$ & $71.24 \pm 1.09^{c}$ & $3.18 \pm 0.64^{\mathrm{cd}}$ & $3.81 \pm 0.46^{\mathrm{h}}$ \\
\hline 16 & 2.0 & 0.0 & 0.20 & $70.59 \pm 0.44^{\mathrm{de}}$ & $4.26 \pm 0.18^{\mathrm{cde}}$ & $4.59 \pm 0.26^{\mathrm{e}}$ & $67.89 \pm 0.39^{\mathrm{de}}$ & $3.06 \pm 0.58^{\mathrm{de}}$ & $3.44 \pm 0.59^{\mathrm{hi}}$ \\
\hline
\end{tabular}

BAP and NAA with IBA to test the shoot proliferation in C. bulbosa. MS medium having $1.0 \mathrm{mg} / 1 \mathrm{BAP}$ alone induced $68.06 \%$ shoot initiation, 3.29 shoots per explant and $5.04 \mathrm{~cm}$ shoot length from the cotyledon derived callus. The highest percentage $(90.91 \%)$ of shoot induction was observed on MS medium fortified with $1.0 \mathrm{mg} / 1 \mathrm{BAP}$ in combination with $0.10 \mathrm{mg} / 1 \mathrm{NAA}$ followed by $81.56 \%$ shooting at $1.0 \mathrm{mg} / 1 \mathrm{NAA}$ in combination with $0.10 \mathrm{mg} / 1 \mathrm{IBA}$ from the cotyledon derived callus. The maximum number of adventitious shoots (4.71) and shoot length $(6.13 \mathrm{~cm})$ was recorded from the cotyledon derived callus, when they were cultured on MS medium supplemented with $1.0 \mathrm{mg} / 1$ BAP in combination with $0.10 \mathrm{mg} / 1 \mathrm{NAA}$ and the same concentration also produced 4.37 number of shoots and $5.78 \mathrm{~cm}$ shoot length from the leaf derived callus (Table 2).

\section{Rooting}

Half strength MS medium fortified with different concentration of IBA, IAA and NAA were used for root induction. Percentage of root induction, number of roots produced per in vitro shoot and root lengths were recorded 4 weeks after culture. Cotyledon derived in vitro shoots could able to produce higher percentage $(92.26 \%)$ of root regeneration on the half-strength MS medium fortified with $0.4 \mathrm{mg} / \mathrm{l} \mathrm{IBA}$. And moreover this concentration could able to produce maximum number roots (13.14) and root length 
Table 3. Effect of different concentration of auxins on root regeneration abilities of the 45 days old cotyledon and leaf callus emerged shoot of $C$. bulbosa. Each value represents the mean $\pm \mathrm{SD}, \mathrm{n}=20$. Mean followed by the same letters in each column are not significantly different at $\mathrm{P}<0.05$ according to Duncan's multiple range test

\begin{tabular}{|c|c|c|c|c|c|c|c|c|c|}
\hline \multirow{2}{*}{ S. No. } & \multicolumn{3}{|c|}{ Plant growth regulators } & \multicolumn{2}{|c|}{$\%$ of rooting } & \multicolumn{2}{|c|}{ No. of roots/shoot } & \multicolumn{2}{|c|}{ Root length (cm) } \\
\hline & IBA & IAA & NAA & Cotyledon & Leaf & Cotyledon & Leaf & Cotyledon & Leaf \\
\hline 1 & 0.2 & 0.0 & 0.0 & $83.48 \pm 0.57^{c}$ & $86.59 \pm 0.62^{\mathrm{c}}$ & $12.36 \pm 0.31^{\mathrm{b}}$ & $12.02 \pm 0.68^{\mathrm{ab}}$ & $8.37 \pm 0.74^{\mathrm{ab}}$ & $6.06 \pm 0.80^{\mathrm{b}}$ \\
\hline 2 & 0.4 & 0.0 & 0.0 & $92.26 \pm 0.68^{a}$ & $89.12 \pm 0.83^{\mathrm{a}}$ & $13.14 \pm 0.52^{a}$ & $12.42 \pm 0.44^{a}$ & $8.87 \pm 0.28^{\mathrm{a}}$ & $7.47 \pm 0.56^{a}$ \\
\hline 3 & 0.6 & 0.0 & 0.0 & $75.44 \pm 1.20^{f}$ & $76.03 \pm 0.21^{\mathrm{d}}$ & $11.22 \pm 1.07^{\mathrm{bc}}$ & $10.45 \pm 0.54^{c}$ & $7.59 \pm 0.61^{\mathrm{c}}$ & $5.87 \pm 1.02^{\mathrm{bc}}$ \\
\hline 4 & 0.8 & 0.0 & 0.0 & $64.07 \pm 0.89^{\mathrm{g}}$ & $72.01 \pm 1.18^{\mathrm{e}}$ & $10.39 \pm 0.42^{\mathrm{cd}}$ & $9.01 \pm 0.57^{\mathrm{e}}$ & $6.65 \pm 0.67^{\mathrm{d}}$ & $5.03 \pm 0.30^{c}$ \\
\hline 5 & 1.0 & 0.0 & 0.0 & $61.03 \pm 1.00^{\mathrm{ij}}$ & $61.71 \pm 0.48^{\mathrm{hi}}$ & $9.93 \pm 1.06^{\mathrm{def}}$ & $8.74 \pm 0.54^{\mathrm{ef}}$ & $6.14 \pm 0.35^{\mathrm{de}}$ & $4.80 \pm 0.60^{\mathrm{cd}}$ \\
\hline 6 & 0.0 & 0.2 & 0.0 & $80.10 \pm 1.07^{\mathrm{d}}$ & $72.69 \pm 0.74^{\mathrm{e}}$ & $11.15 \pm 0.78^{\mathrm{bc}}$ & $9.43 \pm 0.40^{\mathrm{d}}$ & $6.91 \pm 0.67^{\mathrm{cd}}$ & $5.51 \pm 0.29^{\mathrm{bc}}$ \\
\hline 7 & 0.0 & 0.4 & 0.0 & $90.02 \pm 0.68^{b}$ & $87.24 \pm 0.67^{\mathrm{b}}$ & $12.82 \pm 0.52^{\mathrm{b}}$ & $11.79 \pm 0.70^{\mathrm{b}}$ & $8.32 \pm 0.28^{b}$ & $6.05 \pm 0.07^{\mathrm{b}}$ \\
\hline 8 & 0.0 & 0.6 & 0.0 & $72.25 \pm 0.61^{\mathrm{ef}}$ & $69.78 \pm 1.36^{\mathrm{f}}$ & $10.96 \pm 0.94^{\mathrm{c}}$ & $7.76 \pm 0.61^{\mathrm{gh}}$ & $6.0 \pm 0.12^{\mathrm{e}}$ & $5.01 \pm 0.13^{c}$ \\
\hline 9 & 0.0 & 0.8 & 0.0 & $62.24 \pm 0.68^{\mathrm{hi}}$ & $65.27 \pm 1.28^{g}$ & $9.23 \pm 0.67^{\mathrm{ef}}$ & $8.00 \pm 0.12^{\mathrm{f}}$ & $5.26 \pm 0.35^{\mathrm{f}}$ & $4.21 \pm 1.29^{\mathrm{de}}$ \\
\hline 10 & 0.0 & 1.0 & 0.0 & $57.24 \pm 0.76^{\mathrm{k}}$ & $62.22 \pm 1.05^{\mathrm{h}}$ & $9.42 \pm 0.17^{\mathrm{ef}}$ & $6.96 \pm 0.06^{\mathrm{i}}$ & $5.42 \pm 0.51^{\mathrm{ef}}$ & $4.05 \pm 0.47^{\mathrm{e}}$ \\
\hline 11 & 0.0 & 0.0 & 0.2 & $60.35 \pm 1.02^{i}$ & $59.31 \pm 0.63^{\mathrm{i}}$ & $9.00 \pm 0.88^{\mathrm{f}}$ & $7.04 \pm 0.03^{\mathrm{h}}$ & $5.03 \pm 0.49^{g}$ & $4.29 \pm 0.28^{\mathrm{de}}$ \\
\hline 12 & 0.0 & 0.0 & 0.4 & $63.74 \pm 0.97^{\mathrm{gh}}$ & $61.15 \pm 0.70^{\mathrm{hi}}$ & $9.58 \pm 0.44^{\text {def }}$ & $8.26 \pm 0.24^{\mathrm{ef}}$ & $6.37 \pm 0.54^{\text {de }}$ & $4.49 \pm 0.83^{\mathrm{d}}$ \\
\hline 13 & 0.0 & 0.0 & 0.6 & $77.24 \pm 0.70^{\mathrm{e}}$ & $76.77 \pm 1.35^{\mathrm{d}}$ & $10.65 \pm 0.63^{\text {cd }}$ & $9.32 \pm 0.50^{\mathrm{d}}$ & $6.87 \pm 0.28^{\mathrm{cd}}$ & $5.02 \pm 0.35^{c}$ \\
\hline 14 & 0.0 & 0.0 & 0.8 & $55.18 \pm 1.28^{\mathrm{k}}$ & $62.32 \pm 0.94^{\mathrm{h}}$ & $8.75 \pm 0.77^{\mathrm{fg}}$ & $7.25 \pm 0.79^{\mathrm{h}}$ & $5.11 \pm 0.95^{g}$ & $3.95 \pm 0.89^{\mathrm{f}}$ \\
\hline 15 & 0.0 & 0.0 & 1.0 & $52.25 \pm 1.41^{1}$ & $57.95 \pm 1.21^{\mathrm{i}}$ & $7.98 \pm 0.97^{\mathrm{g}}$ & $6.21 \pm 0.62^{\mathrm{i}}$ & $4.96 \pm 0.35^{\mathrm{h}}$ & $3.66 \pm 0.35^{\mathrm{g}}$ \\
\hline
\end{tabular}

$(8.87 \mathrm{~cm})$ followed by $90.02 \%$ rooting and 12.82 roots and $8.32 \mathrm{~cm}$ long root was observed on the medium containing $0.4 \mathrm{mg} / 1$ IAA from the same explant of C. bulbosa. The moderate rooting percentage $(89.12 \%)$, average number of roots $(12.42)$ and root length $(7.47 \mathrm{~cm})$ were noted from the leaf callus derived shoots on $0.4 \mathrm{mg} / 1 \mathrm{IBA}$ containing medium (Table 3). Hardening experiments is one of the important establishment processes of the in vitro raised plantlets of C. bulbosa using different hardening media composition to determine their survivability rate. The highest survivability percentage $(93.3 \%)$ was shown by the cotyledon derived callus plantlets, when they were growing on the hardening media composed of Forest soil: Soil: Vermiculite in 1:1:1 ratio followed by $83.3 \%$ survivability was observed from leaf derived callus plantlets on same hardening media.

\section{I S C U S S I O N}

Observations of the present study indicated that the suitable combinations of auxin and cytokinins were important for caullogenesis from the cotyledon and leaf explants of C. bulbosa. Cotyledon explants of C. bulbosa showed higher percentage of callus induction and multiple shoot formation on the MS medium containing auxin and cytokinin. In the present study, it was observed that the MS medium fortified with $0.5 \mathrm{mg} / 12,4-\mathrm{D}$ in combination with $0.05 \mathrm{mg} / 1 \mathrm{Kn}$ was superior in organogenic potential compared to other growth regulator combinations in the culture of C. bulbosa (Table 1). A number available research reports pointed out that combination of auxins and cytokinins could bring the capability of in vitro propagation in tissue culture. The induction of caulogenesis in cultures requires an adjustment in the levels of auxins and cytokinins based on the type of explants. The 2,4-D is the main synthetic auxin used to induce the callogenesis. Because, one of its main characteristics is the capacity to efficiently stimulate the cell division in plant cell culture (Gaspar et al. 1996, Feher et al. 2003).

Da Silva et al. (2003) noted that $83.2 \%$ and $86.4 \%$ callus formation from the cotyledon and hypocotyl explants of Glycine wightii, when they were cultured on MS medium fortified with $1.0 \mathrm{mg} / 1$ 2,4-D in combination with $0.10 \mathrm{mg} / 1 \mathrm{Kn}$. It was reported that leaf explants of Catha- ranthus roseus cultured on MS medium having $4.06 \mu \mathrm{M} 2,4-\mathrm{D}$ in combination with $2.3 \mu \mathrm{M} \mathrm{Kn}$ could produce good friable, high biomass callus (Garg 2010). The present study is in harmony with the works of Da Silva et al. (2003) and Garg (2010), who used same combination of the 2 plant growth regulators $(2,4-\mathrm{D}+\mathrm{Kn}) \cdot 2,4-\mathrm{D}$ in combination with Kn could induced callus formation in many plant species; Tylophora indica (Sadguna et al., 2013) and Rauvolfia serpentina (Gupta et al., 2014).

The highest percentage $(82 \%)$ of callus induction was observed, when cotyledon explants of Decalepis hamiltonii were cultured on MS medium supplemented with $0.5 \mathrm{mg} / 1$ BAP in combination with $0.05 \mathrm{mg} / 1 \mathrm{Kn}$ (Samydurai et al. 2016). However, the moderate percentage $(86.25 \%$ ) of callus induction in the present study was observed using cotyledon explants cultured on MS medium supplemented with $0.5 \mathrm{mg} / 1 \mathrm{BAP}$ in combination with $0.05 \mathrm{mg} / 1 \mathrm{Kn}$. The results observed in this study are in agreement with the report of Samydurai et al. (2016).

The lower concentration of 2,4-D, BAP and TDZ (0.5 and $1.0 \mathrm{mg} / \mathrm{l}$ ) could induce huge size callus. It was found that there was some green color blotches scattered on the surface of the 4 weeks old callus. The occurrence of green spots on surface of the callus is considered as meristematic centers that indicate the capacity of the callus to produce the adventitious shoots in subsequent culture (Nabors et al. 1982, Ishii 1982). Recently, some workers noticed the appearance of green nodules on the surface of the callus of many plant species, when they were getting callus using different concentration of auxins in combination with cytokinins (Chakradhar \& Pullaiah 2014, Dhir \& Shekhawat 2014). The callus property of the present study is in agreement with the callus nature work of Chakradhar \& Pullaiah (2014), Dhir \& Shekhawat (2014).

In the present study a considerable amount of callus formation was observed from the low concentrations of plant growth hormones containing MS medium, when the cotyledon and leaf explants were cultured. Among the three explants used, higher percentage of callus induction was observed from cotyledon explant. In addition, the color of the callus emerged from the all the three explants on high 
concentrations of 2,4-D, BAP and TDZ (2.0 and $3.0 \mathrm{mg} / \mathrm{l}$ ) containing MS medium turned from green colour to brown colour after 3 weeks of culture. Shoot developments were not possible from these kinds of callus. Similar types of callus were found during in vitro propagation of Sarcostemma acidum (Rathore \& Shekawat 2013).

Compact green calli were transferred to MS medium augmented with varied levels of plant growth regulators to study their effect on shoot regeneration. Fully green coloured callus was not able to regenerate the shoots. Some of them remained whitish green colour patches over the surface and hard in texture only had the capacity of shoot regeneration. The data presented in table 1 indicated that percentage of plant regeneration varied with different hormonal concentrations. Maximum number of shoots and shoot length was recorded from the cotyledon derived callus on MS medium fortified with $1.0 \mathrm{mg} / 1 \mathrm{BAP}$ in combination with $0.1 \mathrm{mg} / 1 \mathrm{NAA}$.

Muthukrishnan et al. (2015) reported the highest percentage of shoot induction from the internode explant derived callus of Ceropegia thwaitesii, when they were cultured on MS medium having $1.0 \mathrm{mg} / 1 \mathrm{BAP}$ in combination with $0.10 \mathrm{mg} / 1 \mathrm{NAA}$. This combination could induce the maximum number of shoots (19.43) and shoot length $(2.99 \mathrm{~cm})$. Epicotyl explant derived callus of C. bulbosa was cultured on MS medium supplemented with $1.0 \mathrm{mg} / 1 \mathrm{BAP}$ in combination with $0.10 \mathrm{mg} / 1 \mathrm{NAA}$, which could produce 25.5 shoots and $4.46 \mathrm{~cm}$ shoot length (Phulwaria et al. 2013). The result of the shoot induction study is in agreement with the results of Muthukrishnan et al. (2015) and Phulwaria et al. (2013), who used very similar concentration and combination of $(1.0 \mathrm{mg} / \mathrm{l}) \mathrm{BAP}$ and $(0.10 \mathrm{mg} / \mathrm{l}) \mathrm{NAA}$.

Singh et al. (2011) achieved shoot proliferation (6.8 11.0$)$ from the hypocotyl derived callus of Catharanthus roseus that were cultured on MS medium supplemented with $1.5 \mathrm{mg} / 1$ BAP in combination with $1.0 \mathrm{mg} / \mathrm{l} \mathrm{NAA}$. Shoots were regenerated from the internodal derived callus of Caralluma stalagmifera, when they were cultured on MS medium supplemented with $2.0 \mathrm{mg} / \mathrm{l} \mathrm{BAP}$ in combination with 0.5 $\mathrm{mg} / 1 \mathrm{NAA}$. This concentration and combination could induce $60 \%$ of shoot regeneration and produce 3.15 shoots per explant (Sreelatha et al. 2015). In the present study the highest percentage $(90.91 \%)$ of shoot initiation, number of adventitious shoots (4.71) and shoot length $(6.13 \mathrm{~cm})$ were observed, when the cotyledon derived callus was cultured on MS medium acuminated with $1.0 \mathrm{mg} / \mathrm{l} \mathrm{BAP}$ in combination with $0.10 \mathrm{mg} / 1 \mathrm{NAA}$. The result of our study is in agreement with in the works of Singh et al. (2011) and Sreelatha et al. (2015), who used BAP in combination with NAA resulted in synergistically increase of shootings in vitro propagation. The inclusion of BAP in combination with NAA in the culture medium has been reported to be necessary for inducing shoot multiplication in some Asclepideaceae members such as Ceropegia bulbosa var. bulbosa (Patil 1998), C. intermedia (Karuppusamy et al. 2009) and Wattakaka volubilis (Vinothkumar et al. 2015).

The efficient root induction of regenerated shoots determines the success of in vitro cultures. Of the three auxins tested, IBA was found to be superior to IAA and NAA. Vi- nothkumar \& Senthilkumar (2015) reported that elongated in vitro shoots of Wattakaka volubilis produced well developed long roots, when they were cultured on half strength MS basal medium supplemented with $0.6 \mathrm{mg} / \mathrm{l} \mathrm{IBA}$ and $3 \%(\mathrm{w} / \mathrm{v})$ sucrose.

When in vitro shoots of $C$. candelabrum were cultured on half strength MS medium having $0.49 \mu \mathrm{M}$ IBA produced $100 \%$ rooting with 6.9 roots/explant (Beena et al. 2003). The highest percentage of rooting $(96 \pm 1.9 \%$ was observed, when microshoots of C.panchganiensis were cultured on half strength MS medium supplemented with $7.36 \mu \mathrm{M}$ IBA, where 9.3 roots $/$ microshoots and $3.6 \mathrm{~cm}$ root length Chavan et al. (2013). When in vitro derived shoots of C. attenuata were cultured on half strength MS medium having $2.46 \mu \mathrm{M}$ IBA, they could induce the highest percentage (100) of root induction and number of (9.8) roots (Chavan et al. 2011). The results of the present study are in agreement with the works of Chavan et al. (2013) and Chavan et al. (2011).

When half strength MS medium was enriched with $0.6 \mathrm{mg} / 1 \mathrm{IAA}$, it could produce desirable percentage of rooting and number of roots as it was noted in the present investigation. Nikam et al. (2007) reported the highest percentage of rooting, number of roots and root length in C. hirsuta, when the nodal explants derived in vitro shoots were cultured on the half strength MS medium fortified with $2.0 \mu \mathrm{M}$ IAA. When the microshoots of Caralluma tuberculata were cultured on half strength MS medium supplemented with $5.07 \mu \mathrm{M}$ IAA, they were produced $3.0 \pm 0.15$ roots/microshoot (Rehman et al. 2014).

Present investigation revealed that higher concentrations of auxins induced the callus formation at the base of the nodal segments explants during root organogensis. Sahoo et al. (1997) and Saha et al. (2010) stated that root development was getting delayed on higher IBA, NAA and IAA concentration containing medium. They further said that at the same time the callus formation took place at the base of the shoots of some other plant species (Sahoo et al. 1997, Saha et al. 2010). Similarly, Nikam et al. (2008) reported that the higher concentrations of IBA, NAA and IAA resulted in swelling and callus formation at the base of the shoots of C. odorata and C. maccannii.

Chavan et al. (2011) stated that MS medium was supplemented with increasing concentration of IAA could produce the callus formation in C. attenuata during in vitro root formation. Baksha et al. (2007) explained that the increasing concentrations of $(1.0 \mathrm{mg} / \mathrm{l}) \mathrm{NAA}$ and IBA could decrease root induction percentage and number of roots per explant, however, it could increase callus formation too. Similarly, the higher concentrations of IBA, IAA and NAA could induce the callus formation rather than rooting. Thus, the present study is in agreement with the works of Baksha et al. (2007), Nikam et al. (2008) and Chavan et al. (2011).

It has been identified that IBA found to have root induction potential compared to the other auxins. However, $0.6 \mathrm{mg} / 1 \mathrm{IBA}$ had a cumulative action, which played a great role in root induction and elongation in C. bulbosa. Though, the explants were cultured on all the three auxins (IBA, IAA and NAA), NAA and IAA exhibited poor response in root 
induction in C. bulbosa. In contrast, some researchers said that NAA and IAA had root organogenesis ability. It has been reported that in vitro derived shoots of Brachystelma glabrum cultured on half strength MS medium having $0.5 \mathrm{mg} / 1$ NAA showed the highest rooting percentage $(80 \%)$, root numbers (5.3) and root $(6.4 \mathrm{~cm})$ length (Lakshmi et al. 2017). The best rooting response was obtained from the in vitro shoots of Caralluma bhupenderiana in a medium containing 2.69 $\mu \mathrm{M}$ NAA (Ugraiah et al. 2011). Nikam et al. (2008) stated that MS medium was supplemented with 2.0 $\mu \mathrm{M}$ IAA showed the highest rooting percentage $(74.6 \%)$ and root numbers (2.8). However, they could able to get significant root induction when NAA was combined with IBA. But, in this present investigation, the best root induction was obtained on MS medium supplemented with $0.4 \mathrm{mg} / 1 \mathrm{IBA}$ in C. bulbosa.

Best rooting was also observed in many Asclepideaceae members such as Gymnema sylvestre (Komalavalli \& Rao 2000), Ceropegia candelabrum (Beena et al. 2003), C. thwaitesii (Muthukrishnan et al. 2012), C. bulbosa and C. juncea (Subbaiyan et al. 2015). MS medium fortified either with individual different concentrations of auxins or in combination with cytokinins could induce callus, somatic embryogenesis, proliferations of shoot and root, tuber formations and enhance the secondary metabolites productions as reported by many researchers (Ghanti et al. 2004, Desai et al. 2014).

As in vitro callogenesis and shoot multiplication process were achieved using cotyledonary explants of C. bulbosa, this kind of in vitro propagation should have been useful for the conservation as well as mass propagation of C. bulbosa. It can also be possible to enhance the secondary metabolite, cerpegin using cell suspension culture. However, an effort will be taken to improve mass propagation on low cost to reinstate this plant into its wild habitats.

\section{ACKNOWLEDGEMENTS}

The authors are grateful to Dr. M. Aruchami, President, Dr. C.A. Vasuki, Secretary and Director and Dr. V. Balasubramaniam, Principal, Kongunadu Arts and Science College, Coimbatore for their continuous encouragement and support. Authors are gratefully acknowledging Tamil Nadu Forest Department to permit me to conduct the periodical field survey.

\section{LITERATURE CITED}

Baksha, R., M.A.A. Jahan, R. Khatun \& J.L. Munshi 2007. In vitro rapid clonal propagation of Rauvolfia serpentina (Linn.) Benth. Bangladesh Journal of Scientific and Industrial Research 42(1):37-44.

Beena, M.R., K.P. Martin, P.B. Kirti \& M. Hariharan 2003. Rapid in vitro propagation of medicinally important Ceropegia candelabrum. Plant Cell, Tissue and Organ Culture 72: 285-289.

Bowes, B.G. 1999. A colour atlas of plant propagation and conservation. Manson Publishing Ltd, London.

Cerabolini, B., R. De Andreis, R.M. Ceriani, S. Pierce \& B. Raimondi 2004. Seed germination and conservation of endangered species from the Italian Alps: Physoplexis comosa and Primula glaucescens. Biological Conservation 117:351-356.

Chakradhar, T \& T. Pullaiah 2014. In vitro regeneration through adventitious buds in Wattakaka volubilis, a rare medicinal plant. African Journal of Biotechnology 13(1):55-60.

Chavan J.J., M.S. Nimbalkar, A.A. Adsul, S.S. Kamble, N.B. Gaikwad, G.B. Dixit, R.V. Gurav, V.B. Bapat \& S.R. Yadav 2011. Micropropagation and in vitro flowering of endemic and endangered plant Ceropegia attenuata Hook. Plant Biochemistry and Biotechnology 20:276-282.

Chavan, J.J., N.B. Gaikwad \& S.R. Yadav 2013. High multiplication frequency and genetic stability analysis of Ceropegia panchganiensis a threatened ornamental plant of Western Ghats: conservation implications. Scientia Horticulturae 161:134-142.

Da Silva, A.L., C.S. Caruzo, R.A. Moreira \& A.C.G. Horta 2003. In vitro induction of callus from cotyledon and hypocotyl explants of Glycine wightii (Wight \& Arn.) Verdc. Ciência e Agrotecnologia 27:1277-1284.

Desai, M.T., S.S. Kambale, A.S. Nalwade, N.B. Gaikwad, R.V. Gurav, G.B. Dixit \& S.R. Yadav 2014. In vitro propagation of Ceropegia fimbriifera Bedd., an endangered, endemic plant of South India. Journal of International Academic Research for Multidisciplinary 2:124-132.

Dhir, R \& G.S. Shekhawat 2014. In vitro propagation using transverse thin cell layer culture and homogeneity assessment in Ceropegia bulbosa Roxb. Journal of Plant Growth Regulation 33:820-830.

Feher, A., T. Pasternak \& D. Dudits 2003. Transition of somatic plant cells to an embryogenic state. Plant Cell, Tissue and Organ Culture 74(3):201-228.

Garg, G. 2010. In vitro screening of Catharanthus roseus L. cultivars for salt tolerance using physiological parameters. International Journal of Environmental Science and Development $1(1): 24-30$.

Gaspar, T., C. Kevers, C. Penel, H. Greppin, D.M. Reid \& T. Thorpe 1996. Plant hormones and plant growth regulators in plant tissue culture. In vitro Cellular and Developmental Biology - Plant 32(4):272-289.

Ghanti, K.S., B. Govindaraju, R.B. Venugopal, S. Ramgopal Rao, C.P. Kaviraj, F.T.Z. Jabeen, A. Barad \& S. Rao 2004. High frequency shoot regeneration from Phyllanthus amarus Schum. \& Thonn. Indian Journal of Biotechnology 3:103-107.

Goyal, D \& S. Bhadauria 2006. In vitro propagation of Ceropegia bulbosa using nodal segments. Indian Journal of Biotechnology 5:565-567.

Gupta, N.S., M. Banerjee \& K. Acharya 2014. Influence of hormones and explants towards in vitro callusing and shoot organogenesis in Rawvolfia serpentina a commercially important medicinal plant. International Journal of Pharmaceutical Sciences Review and Research 29(2):132-137.

Ishii, C. 1982. Callus induction and shoot differentiation of wheat, oat and barley. In: Proceedings of the 5 th International congress of plant tissue culture and cell culture (A. Fujiwara, ed.), pp. 185-186, Japanese Association for Plant Tissue Culture, Tokyo.

Karuppusamy, S., C. Kiranmani, V. Aruna \& T. Pullaiah 2009. In vitro conservation of Ceropegia intermedia - an endemic plant of South India. African Journal of Biotechnology 8:236-239.

Komalavalli, N \& M.V. Rao 2000. In vitro micropropagation of Gymnema sylvestre - a multipurpose medicinal plant. Plant Cell, Tissue and Organ Culture 61:97-105.

Krishnareddy, P.V., S. Karuppusamy \& T. Pullaiah 2011. In vitro propagation of Ceropegia juncea Roxb. African Journal of Plant Science 5(14):813-818.

Lakshmi, S.R., Parthibhan, S., Sherif, N.A., T. Senthil Kumar \& M.V. Rao 2017. Micropropagation, in vitro flo- 
wering and tuberization in Brachystelma glabrum Hook. f., an endemic species. In vitro Cellular \& Developmental Biology - Plant 53(1): 64-72.

Muthukrishnan, S., J.H. Franklin Benjamin, M. Muthukumar, N. Ahamed sheriff, T. Senthilkumar \& M.V. Rao 2012. In vitro propagation of Ceropegia thwaitesii Hook - an endemic species of Western Ghats of Tamil Nadu, India. African Journal of Biotechnology 11(59):1277-1285.

Muthukrishnan, S., T. Senthil Kumar \& M.V. Rao 2015. An efficient in vitro regeneration and ex vitro rooting of Ceropegia thwaitesii: an endemic species from Western Ghats. International Journal of Pharmaceutical Sciences Review and Research 30(2):202-211.

Nabors, M.W., C.S. Kroskey \& D.M. Mc Hugh 1982. Green spots are predictors of high callus growth rates and shoot formation in normal and in salt stressed tissue cultures of oat (Avena sativa L). Zeitschrift für Pflanzenphysiologie 105: 341-349.

Nikam, T.D., M.A. Ebrahimi, R.S. Sawant, S. Jagtap \& P.P. Patil 2008. Ecorestoration of Ceropegia odorata Hook and C. maccannii Ansari, endangered Asclepiads, by micropropagation. Asian and Australasian Journal of Plant Science and Biotechnology 2(2):80-83.

Nikam, T.D., R.S Savant \& R.S. Pagare 2008. Micropropagation of Ceropegia birsuta - a starchy tuberous asclepid. Indian Journal of Biotechnology 5:129-132.

Patil, V.M. 1998. Micropropagation studies in Ceropegia spp. In vitro Cellular and Development Biology - Plant 30: 240-243.

Phulwaria, M., N.S. Shekhawat, J.S. Rathore \& R.P. Singh 2013. An efficient in vitro regeneration and ex vitro rooting of Ceropegia bulbosa Roxb. - a threatened and pharmaceutical important plant of Indian Thar desert. Industrial Crops and Products 42: 25-29.

Rathore M.S \& N.S. Shekhawat 2013. In vitro regeneration in Sarcostemma acidum (Roxb.) - an important medicinal plant of semi-arid ecosystem of Rajasthan, India. Physiology and Molecular Biology of Plants 19(2):269-275.

Rehman, R.U., M.F. Chaudhary, K.M. Khawar, G. Lu, A. Mannan \& M. Zia 2014. In vitro propagation of Caralluma tuberculata and evaluation of antioxidant potential. Biologia 69(3):341-349.

Sadguna, V., T.N. Swamy, S. Raju, M.D. Ghani, V. Suresh \& M.D. Mustafa 2013. High frequency regeneration of plantlets from leaf derived callus cultures of Tylophora indica Burmf., an important medicinal plant. International Journal of Scientific and Engineering Research 4(9):2704-2707.

Saha, S., T. Dey \& P. Ghosh 2010. Micropropagation of Ocimum kilimandscharicum Guerke (Labiatae). Acta Biologica Cracoviensia Series Botanica 52(2):50-58.

Sahoo, Y., S.K. Pattnaik \& P.K. Chand 1997. In vitro clonal propagation of an aromatic medicinal herb Ocimum basili- cum L. (sweet basil) by axillary shoots proliferation. In vitro Cellular and Developmental Biology - Plant 33(4):293-296.

Samydurai, P., M. Saradha, R. Ramakrishnan, S. Santhosekumar \& V. Thangapandian 2016. Micropropagation prospective of cotyledonary explants of Decalepis hamiltonii Wight et Arn. - an endangered edible species. Indian Journal of Biotechnology 15:256-260.

Singh, R., P. Kharb \& K. Rani 2011. Rapid micropropagation and callus induction of Catharanthus roseus in vitro using different explants. World Journal of Agricultural Sciences 7(6):699-704.

Sreelatha, V., M. Thippeswamy \& T. Pullaiah 2015. In vitro callus induction and plant regeneration from internodal explants of Caralluma stalagmifera Fischer. International Journal of Advanced Research 3(2):472-480.

Srinivasarao, C., A. Soni, M.E. Dulloo, \& S.C. Naithani 2010. Overcoming physiological dormancy in Ceropegia odorata seeds, an endangered rare species, with GA3, $\mathrm{H}_{2} \mathrm{O}_{2}$ and $\mathrm{KNO}_{3}$. Seed Science and Technology 38:341-347.

Subbaiyan, B., P. Samydurai, R. Venkatesh \& V. Thangapandian 2015. In vitro multiple shoot induction of selected Ceropegia species - medicinally important plants. International Journal of Conservation Science 6(2):253-260.

Swarnkar, S \& S.S. Katewa 2008. Ethnobotanical observation on tuberous plants from tribal area of rajasthan (India). Ethnobotanical Leaflets 12:647-666.

Thiyagarajan, M \& P. Venkatachalam 2012. Large scale in vitro propagation of Stevia rebaudiana (Bert) for commercial application: pharmaceutically important and antidiabetic medicinal herb. Industrial Crops and Products 37(1):111-117.

Ugraiah, A., V.R. Sreelatha, P.V. Krishna Reddy, K. Rajasekhar, S. Sandhya Rani, S. Karuppusamy \& T. Pullaiah 2011. In vitro shoot multiplication and conservation of Caralluma bhupenderiana Sarkaria - an endangered medicinal plant from South India. African Journal of Biotechnology 10(46):9328-9336.

Upadhye, A.S., P.B. Waghamode, P.M. Dhavare \& N.S. Gaikwad 2014. Standardization and re-introduction of critically endangered Ceropegia mababalei Hemadri and Ansari by in vitro propagation. Annals of Plant Sciences 4(2): 987-993.

Vinothkumar, D \& M. Senthilkumar 2015. In vitro callus induction and plants from leaf explants of Wattakaka volubilis L. (Staf. Arn) - an vulnerable medicinal plant. European Journal of Biotechnology and Bioscience 3(6):12-16.

Yadav, S.R \& M.Y. Kamble 2008. Threatened Ceropegias of the Western Ghats and strategies for their conservation. Special Habitats and Threatened Plants of India. ENVIS Bulletin 11(1):1-239. 